\title{
FITUR MORFOLOGI SECARA KUANTITATIF SAPI BALI KECAMATAN PAMENANG DAN BANGKO KABUPATEN MERANGIN
}

\section{QUANTITATIVE MORPHOLOGY FEATURES OF BALI COW, PAMENANG DISTRICT AND BANGKO IN MERANGIN DISTRICT}

\author{
Maimunah $^{1 a}$, Depison ${ }^{1}$, dan E Wiyanto \\ ${ }^{1}$ Program Studi Peternakan Fakultas Peternakan Universitas Jambi Jl. Jambi - Ma. Bulian KM. 15 \\ Mendalo Darat kode pos 36361 \\ ${ }^{a}$ Korespondensi: Depison, E-mail: depison.nasution@yahoo.com
}

(Diterima oleh Dewan Redaksi: 15-07-2020)

(Dipublikasikan oleh Dewan Redaksi: 30-04-2021)

\begin{abstract}
This research aims to determine the morphological features quantitatively of Bali cattle in Pamenang and Bangko Districts, Merangin District. The method used in this research is the survey. The sampling technique was purposive sampling. Age of livestock taken is the age of I1 and the samples in each district are 60 heads consisting of 30 males and 30 females. The data collected were Body Weight (BB), growth $(\mathrm{PBBH})$ and body measurements include Body Length, Shoulder Height, Chest Circumference, Chest Width, Chest Width, Canon Circumference, and Hip Height. Data were analyzed using a t-test. Analysis of the main components to determine the determinants of the size and shape of Bali cattle and regression analysis and correlation is used to determine the close relationship between body size and body weight. The results showed that BB, PBBH and body measurements of male Bali cattle between Pamenang and Bangko Districts, and female Bali cows in Pamenang District and Bangko females were not significantly different $(\mathrm{P}>0.05)$, but between male and female Balinese cattle Pamenang and Bangko Sub-districts were significantly different $(\mathrm{P}<0.05)$. The conclusions BB, $\mathrm{PBBH}$, and body measurements of male and female Bali cattle in Pamenang District are higher than Bangko District. The determinants of the body size and shape of Bali cattle male and female cows in Pamenang and Bangko Sub-districts are Chest Circumference and Shoulder Height. The correlation between body measurements with the highest body weight in male and female Bali cattle in the two districts is the Chest Circumference. The body size of male and female Balinese cattle in Pamenang and Bangko Districts has fulfilled the minimum requirements for SNI class III.
\end{abstract}

Keywords: Features, Body Measures, Analysis of Main Components and Bali Cattle

\begin{abstract}
ABSTRAK
Penelitian ini bertujuan untuk mengetahui fitur morfologi secara kuantitatif sapi Bali Kecamatan Pamenang dan Bangko Kabupaten Merangin. Metode yang digunakan dalam penelitian adalah survey. Teknik pengambilan sampel secara purpossive sampling. Umur ternak yang diambil adalah umur $\mathrm{I}_{1}$ dan jumlah sampel masing-masing kecamatan sebanyak 60 ekor yang terdiri dari 30 ekor jantan dan 30 ekor betina. Data yang dihimpun adalah Bobot Badan (BB), pertambhan bobot badan harian (PBBH) dan ukuran-ukuran tubuh meliputi: Panjang Badan, Tinggi Pundak, Lingkar dada, Dalam Dada, Lebar Dada, Lingkar Kanon dan Tinggi Pinggul. Data dianalisis menggunakan uji t. Analisis komponen utama untuk mengetahui faktor penentu ukuran dan bentuk sapi Bali serta analisis korelasi dan determinasi digunakan untuk mengetahui keeratan hubungan antara ukuran tubuh dengan bobot badan. Hasil penelitian menunjukan bahwa BB, PBBH dan ukuran-ukuran tubuh sapi Bali jantan antara Kecamatan Pamenang dan Bangko, serta sapi Bali betina di Kecamatan Pamenang dengan betina Bangko berbeda tidak nyata $(P>0,05)$, namun antara sapi Bali jantan dan betina di Kecamatan Pamenang dan Bangko berbeda nyata $(\mathrm{P}<0,05)$. Kesimpulan BB, PBBH dan ukuranukuran tubuh sapi Bali jantan dan betina di Kecamatan Pamenang lebih tinggi dibandingkan Kecamatan Bangko. Penentu penciri ukuran dan bentuk tubuh sapi Bali jantan dan betina di Kecamatan Pamenang dan Bangko secara berurutan adalah Lingkar Dada dan Tinggi Pundak. Korelasi antara ukuran-ukuran tubuh dengan bobot badan yang tertinggi pada sapi Bali jantan
\end{abstract}


maupun betina di dua kecamatan adalah Lingkar Dada. Ukuran tubuh sapi Bali jantan dan betina di Kecamatan Pamenang dan Bangko sudah memenuhi persyaratan minimum SNI kelas III.

Kata Kunci : Fitur, Ukuran-ukuran Tubuh, Analisis Komponen Utama dan Sapi Bali.

Maimunah. Depison dan E Wiyanto.2021. Fitur Morfologi secara kuantitatif Sapi Bali Kecamatan Pamenang dan Bangko kabupaten Merangin. Jurnal Peternakan Nusantara 7 (1): 51-58.

\section{PENDAHULUAN}

Indonesia merupakan salah satu Negara yang memiliki keanekaragaman hayati yang sangat kaya, diantaranya yaitu keanekaragaman ternak sapi lokal. Sapi lokal dipelihara untuk menghasilkan daging, pupuk dan tenaga kerja. Sapi yang dipelihara dengan tujuan utama mengahasilkan daging disebut sapi potong yang penyebarannya hampir merata diseluruh Indonesia salah satunya di Provinsi Jambi. Populasi ternak sapi potong di Provinsi Jambi mengalami peningkatan dalam kurun waktu tahun 2014 sampai tahun 2018 dari 136.637 ekor menjadi 161.667 ekor dengan kenaikan populasi hanya $2.27 \%$ per tahun (Ditjenpkh, 2018). Sapi potong yang ada di Provinsi Jambi penyebaran salah satunya yang terbesar adalah Kabupaten Merangin. Total sapi potong yang ada di Kabupaten Merangin pada tahun 2014 sebanyak 15.431 ekor sedangkan pada tahun 2018 sebanyak 16.703 ekor dengan kenaikan populasi hanya 2,06 \% per tahun (BPS Provinsi Jambi, 2014; BPS Provinsi Jambi, 2018). Dari data diatas menunjukan bahwa kenaikan populasi sapi potong masih relative kecil, hal ini diduga sebagai akibat penurunan mutu genetik dan faktor lain seperti manajemen pemeliharaan yang kurang tepat (Harahap, 2018). Mayoritas peternakan sapi di Kabupaten Merangin menggunakan sistem pemeliharaan semi intensif salah satunya Kecamatan Pamenang (trans) karena banyak terdapat lahan kosong yang dapat dimanfaatkan untuk tempat pengembalaan, walaupun demikian pada malam hari sapi tetap diberikan rumput. Sedangkan Kecamatan Bangko (non trans) karena semakin sedikitnya lahan kosong mengharuskan peternak merubah sistem pemeliharaan menjadi intensif dan umumnya sapi potong yang banyak dipelihara adalah sapi Bali.

Menurut Madu et al. (2015) sapi Bali (Bossondaicus) merupakan hasil domestikasi dari Banteng ( Bos javanicus) yang terjadi pada 3500 tahun SM dan merupakan sumber daya genetik asli Indonesia. Sumber daya genetik sapi Bali merupakan salah satu aset nasional yang merupakan plasama nutfah yang perlu dipertahankan keberadaannya. Sapi Bali dikembangkan, dimanfaatkan dan dilestarikan sebagai sumber daya ternak asli yang mempunyai ciri khas tertentu dan mempunyai kemampuan untuk dikembangkan dengan baik diberbagai lingkungan yang ada di Indonesia (Hikmawaty et al., 2014).

Sapi Bali menjadi primadona peternakan rakyat karena memiliki beberapa keunggulan yaitu, kemampuan adaptasi yang cukup baik pada berbagai kondisi lingkungan dan pakan yang kurang baik serta kemampuan dan reproduksinya tinggi. Kemampuan tersebut merupakan faktor pendukung keberhasilan budidaya sapi Bali (Ni'am et al., 2012). Keberhasilan pemeliharaan sapi Bali dapat dilihat dari tingkat produktivitasnya yang dapat digambarkan dari pertumbuhan.

Upaya yang dapat dilakukan untuk mengetahui tingkat produktivitas sapi Bali salah satunya adalah dengan mencari data dasar fitur morfologi yang dapat digambarkan dari sifat kuantitatif. Fitur morfologi merupakan ukuranukuran tubuh ternak yang bermanfaat dalam melengkapi kebutuhan data untuk perbaikan mutu genetik ternak (Hartati et al., 2010). Data fitur morfologi sapi Bali dapat digambarkan diantaranya dari ; bobot baan (BB), pertambahan bobot badan (PBB), panjang badan (PB), tinggi pundak, (TP), lingkar dada (LD), dalam dada (DaD), lebar dada (LeD) tinggi pinggul (TPi) dan lingkar kanon (LK).

Sampai saat ini data fitur morfologi sapi Bali secara kuantitatif belum banyak diketahui. Padahal fitur morfologi dapat dijadikan sebagai dasar yang sangat penting untuk mengetahui karakteristik ternak tersebut, sebagai bahan pertimbangan seleksi, pemanfaatan sumber daya genetik dan perencanaan pengembangan sapi Bali dimasa yang akan datang.

\section{MATERI DAN METODE}

Penelitian ini dilaksanakan dari tanggal 19 Februari sampai tanggal 20 Maret 2020 di Kecamatan Pamenang dan Kecamatan Bangko 
Kabupaten Merangin Provinsi Jambi. Materi penelitian adalah ternak sapi Bali jantan dan betina umur I1serta tidak dalam keadaan bunting. Peralatan yang digunakan adalah alat tulis, tongkat ukur, pita ukur, timbangan dan kamera digital.

Metode yang digunakan dalam penelitian ini adalah survey. Teknik pengambilan sampel secara purpossive sampling dengan data kuantitatif meliputi ; Panjang Badan (PB), Bobot Badan (BB), Tinggi Pundak (TP), Lingkar dada (LiD), Dalam Dada (DaD), Lebar Dada (LeD), Lingkar kanon(LK) dan Tinggi Pinggul (TPi). Jumlah sampel masing-masing kecamatansebanyak 60 ekor yang terdiri dari 30 ekor jantan dan 30 ekor betina pada umur 12 tahun (I1 = sepasang gigi tetap). Sehingga jumlah total keseluruhan sampel kedua lokasi sapi Bali sebanyak 120 sampel.

Data yang telah dikumpulkan dikelompokkan berdasarkan jenis kelamin dan Kecamatan. Selanjutnya dilakukan analisis uji beda rata-rata (uji t) antara jenis kelamin jantan dan betina antara Kecamatan Pamenang dan Kecamatan Bangko dan antar jantan dan betina dalam satu Kecamatan. Rumus uji t yang digunakan adalah sebagai berikut (Gaspersz, 2006).

$$
\mathrm{t}=\frac{\bar{X}_{1}-\bar{X}_{2}}{\sqrt{\frac{\sum\left(X_{J 1}-\bar{X}_{1}\right)^{2}}{n_{1}\left(n_{1}-1\right)}+\frac{\sum\left(X_{J 2}-\bar{X}_{2}\right)^{2}}{n_{2}\left(n_{2}-1\right)}}}
$$

\section{Keterangan :}

$\mathrm{t}=$ nilai $\mathrm{t}$ hitung

$(\mathrm{X})^{-i}=$ rataan sampel pada kelompok pertama,

$\mathrm{X} 2$ = rataan sampel pada kelompok kedua,

$\mathrm{X}_{-} \mathrm{j} 1=$ nilai pengamatan ke-J pada kelompok pertama

$\mathrm{X}_{-} \mathrm{j} 2$ = nilai pengamatan ke-J pada kelompok kedua

$\mathrm{n} 1=$ jumlah sampel pada kelompok pertama, dan

n2 = jumlah sampel pada kelompok kedua.

AKU adalah teknik statistik yang digunakan pada sekumpulan data yang saling berkorelasi. Tujuannya ialah untuk menemukan sejumlah variabel yang koheren dalam subkelompok, yang secara relatif independen terhadap yang lain. Perbedaan ukuran dan bentuk tubuh yang diamati dianalisis berdasarkan Analisis Komponen Utama (AKU). Persamaan ukuran dan bentuk diturunkan dari matriks kovarian.Model matematika yang digunakan untuk analisis ini (Gaspersz, 2006). Persamaan ukuran diperoleh dari persamaan skor komponen utama ke-1 (keragaman total tertinggi), sedangkan persamaan bentuk diperoleh dari persamaan skor komponen ke-2 (keragaman total setelah yang tertinggi).

Selanjutnya data yang dihimpun, lingkar dada, lebar dada, dalam dada, tinggi pundak, panjang badan, tinggi pinggul, lebar pinggul dan lingkar kanon yang dikelompokkan berdasarkan jenis kelamin dan antar lokasi. Data yang di dapat dianalisis dengan menggunakan analis korelasi.

Korelasi antara variabel ukuran linear permukaan tubuh dan bobot badan dihitung berdasarkan rumus menurut (Alhamdi, 2016) sebagai berikut:

$$
r_{x y}=\frac{n \sum x_{i} y_{i}-\left(\sum x_{i}\right)\left(\sum y_{i}\right)}{\sqrt{\left\{n \sum x_{1}^{2}-\left(\sum x_{i}\right)^{2}\right\}}\left\{n \sum y_{2}^{1}-\left(\sum y_{i}\right)^{2}\right\}}
$$

Keterangan:

rxy $=$ Korelasi Pearson

$\mathrm{x}$ = Ukuran-ukuran tubuh

$\mathrm{y}=$ Bobot badan

\section{HASIL DAN PEMBAHASAN}

Bobot Badan dan Pertambahan Bobot Badan Harian sapi Bali

Rataan bobot badan dan pertambahan bobot badan harian sapi Bali umur $I_{1}$ di Kecamatan Pamenang dan Kecamatan Bangko Kabupaten Merangin dapat dilihat pada tabel 1.

Berdasarkan Tabel 1. Menunjukkan bahwa rata-rata bobot badan sapi Bali jantan dan betina di Kecamatan Pamenang secara berurutan adalah $206,07 \pm 19,35 \mathrm{~kg}$ dan $194,85 \pm 10,34 \mathrm{~kg}$ sedangkan Kecamatan Bangko $203,58 \pm 18,68 \mathrm{~kg}$ dan $190,43 \pm 11,17 \mathrm{~kg}$. Hasil penelitian ini lebih rendah jika dibandingkan dengan hasil penelitian Hikmawaty et al. (2014) yang menyatakan bahwa bobot badan sapi Bali jantan dan betina di VBC Kab. Barru Sulsel dan BPTU Pulukan Bali secara berurutan adalah $238,54 \pm 4,46 \mathrm{~kg}$ dan $210,01 \pm 10,7 \mathrm{~kg}$.

Berdasarkan hasil analisis statistik uji beda rata-rata menunjukkan bahwa bobot badan sapi Bali jantan di Kecamatan Pamenang berbeda tidak nyata $(\mathrm{P}>0,05)$ dengan sapi Bali jantan di Kecamatan Bangko, demikian juga sapi Bali betina Kecamatan Pamenang berbeda tidak nyata $(\mathrm{P}>0,05)$ dengan sapi Bali betina di Kecamatan Bangko. Namun bobot badan antara jantan dan betina sapi Bali baik di Kecamatan Pamenang maupun Kecamatan Bangko berbeda nyata $(\mathrm{P}<0,05)$. 
Tabel 1.Rataan bobot badan dan pertambahan bobot badan harian sapi Bali jantan dan betina di Kecamatan Pamenang dan Kecamatan Bangko Kabupaten Merangin

\begin{tabular}{llcccc}
\hline & & \multicolumn{2}{c}{ Pamenang } & \multicolumn{2}{c}{ Bangko } \\
\cline { 3 - 6 } & & Jantan & Betina & Jantan & Betina \\
\hline BB & Kg & $206,07 \pm 19,35^{\mathrm{a}}$ & $194,85 \pm 10,34^{\mathrm{b}}$ & $203,58 \pm 18,68^{\mathrm{a}}$ & $190,43 \pm 11,17^{\mathrm{b}}$ \\
PBBH & $\mathrm{kg}$ & $0,263 \pm 0,032^{\mathrm{a}}$ & $0,243 \pm 0,032^{\mathrm{b}}$ & $0,252 \pm 0,030^{\mathrm{a}}$ & $0,226 \pm 0,031^{\mathrm{b}}$ \\
\hline
\end{tabular}

Keterangan : Huruf yang beda pada baris yang sama kolom berbeda menunjukkan Beda Nyata $(\mathrm{P}<0,05)$, BB (Bobot Badan) dan PBB (Pertambahan Bobot Badan).

Hasil penelitian tidak jauh berbeda dengan hasil penelitian Hikmawaty et al. (2014) yang menyatakan bahwa bobot sapi Bali jantan lebih tinggi dibandingkan dengan sapi Bali betina yang berasal dari Sulsel dan Bali pada umur yang sama. Hal ini disebabkan adanya pengaruh hormon jenis kelamin, dimana mengakibatkan pertumbuhan pada ternak jantan lebih cepat dibandingkan pada betina. Setiyono et al. (2017) menyatakan bahwa pertumbuhan yang lebih cepat terjadi pada ternak jantan dibandingkan ternak betina merupakan akibat dari hormone steroid berupa hormone testosterone yang dihasilkan oleh testis.

Rataan pertambahan bobot badan harian sapi Bali jantan dan betina di Kecamatan Pamenang pada penelitian ini berturut-turut adalah $0,263 \pm 0,032 \mathrm{~kg} / \mathrm{ekor} / \mathrm{hari}$ dan $0,243 \pm 0,032$ $\mathrm{kg} /$ ekor/hari, sedangkan pada sapi Bali jantan dan betina Kecamatan Bangko berturut-turut adalah $0,252 \pm 0,030 \mathrm{~kg} / \mathrm{ekor} / \mathrm{hari}$ dan $0,226 \pm 0,031 \mathrm{~kg} /$ ekor/hari.

Hasil tersebut lebih tinggi dibandingkan hasil dari penelitian Chadijah (2012) yang menyatakan bahwa pertambahan bobot badan harian sapi Bali jantan sebesar 0,21 $\pm 0,04$ $\mathrm{kg} / \mathrm{ekor} / \mathrm{hari}$, sedangkan pada sapi Bali betina sebesar 0,15 \pm 0,03 kg/ekor/hari.

Berdasarkan hasil analisis statistik uji beda ratarata menunjukkan bahwa pertambahan bobot badan harian jantan sapi Bali di Kecamatan Pamenang dan Kecamatan Bangko berbeda tidak nyata $(P>0,05)$, demikian juga pada sapi Bali betina baik di Kecamatan Pamenang dan Kecamatan Bangko berbeda tidak nyata $(\mathrm{P}>0,05)$. Namun pertambahan bobot badan harian antara sapi Bali jantan dan betina baik di Kecamatan Pamenang dan Kecamatan Bangko berbeda nyata $\quad(\mathrm{P}<0,05)$.

Rataan bobot badan dan pertambahan bobot badan harian sapi Bali jantan dan betina di Kecamatan Pamenang lebih tinggi dibandingkan dengan sapi Bali Kecamatan Bangko, artinya sapi Bali di Kecamatan Pamenang memiliki kemampuan produksi yang lebih baik dibandingkan dengan sapi Bali di Kecamatan Bangko. Hal ini di duga karena adanya perbedaan genetik (keturunan), pemberian pakan dan sistem manajemen pemeliharaan pada daerah tersebut. Penelitian ini sesuai dengan pendapat Hikmawaty et al. (2018) bahwa bobot badan ternak dapat berbeda antara satu sama lain yang kemungkinan adanya perbedaan keragaman disebabkan oleh potensi genetik, lokasi asal, sistem pemeliharaan dan perkawinan yang ditetapkan di daerah tersebut.

Ukuran-ukuran Tubuh Sapi Bali di Kecamatan Pamenang dan Kecamatan Bangko

Secara umum hasil ukuran-ukuran tubuh sapi Bali jantan dan betina yang meliputi: PB, TP, LD, DaD, LeD, LK dan TPi di Kecamatan Pamenang lebih tinggi dibandingkan dengan ukuranukuran tubuh sapi Bali di Kecamatan Bangko, artinya sapi Bali di Kecamatan Pamenang memiliki kemampuan produksi yang lebih baik di bandingkan dengan sapi Bali Kecamatan Bangko. Hal ini sesuai dengan pendapat Hartati et al. (2010) bahwa perbedaan ukuran-ukuran tubuh antar lokasi kemungkinan disebabkan karena

berbagai faktor antara lain pengaruh lingkungan, pemberian pakan yang diberikan dan sistem manajemen pemeliharaan

Penentu Penciri Ukuran dan Penciri Bentuk Tubuh sapi di Kecamatan Pamenang dan Kecamatan Bangko Kabupaten Merangin.

Analisis komponen utama penciri ukuran, penciri bentuk, keragaman total, dan nilai eigen ternak sapi Bali disajikan pada Tabel 3. 
Tabel 2. Rataan ukuran- ukuran tubuh sapi Bali di Kecamatan Pamenang dan Kecamatan Bangko Kabupaten Merangin

\begin{tabular}{llcccc}
\hline \multicolumn{2}{c}{ Ukuran-ukuran Tubuh } & \multicolumn{2}{c}{ Pamenang } & \multicolumn{2}{c}{ Bangko } \\
\cline { 3 - 6 } & & Jantan & Betina & Jantan & Betina \\
\hline PB & $(\mathrm{cm})$ & $114,30 \pm 3,46^{\mathrm{a}}$ & $104,43 \pm 3,79^{\mathrm{b}}$ & $113,18 \pm 3,31^{\mathrm{a}}$ & $104,10 \pm 2,79^{\mathrm{b}}$ \\
TP & $(\mathrm{cm})$ & $104,87 \pm 2,62^{\mathrm{a}}$ & $103,33 \pm 2,62^{\mathrm{b}}$ & $104,85 \pm 4,70^{\mathrm{a}}$ & $102,83 \pm 2,57^{\mathrm{b}}$ \\
LD & $(\mathrm{cm})$ & $140,83 \pm 3,12^{\mathrm{a}}$ & $128,70 \pm 4,24^{\mathrm{b}}$ & $139,78 \pm 4,51^{\mathrm{a}}$ & $127,60 \pm 4,47^{\mathrm{b}}$ \\
DaD & $(\mathrm{cm})$ & $47,70 \pm 3,57^{\mathrm{a}}$ & $43,93 \pm 1,75^{\mathrm{b}}$ & $47,53 \pm 2,68^{\mathrm{a}}$ & $43.30 \pm 2,10^{\mathrm{b}}$ \\
LeD & $(\mathrm{cm})$ & $33,65 \pm 1,46^{\mathrm{a}}$ & $31,10 \pm 1,94^{\mathrm{b}}$ & $32.97 \pm 2,25^{\mathrm{a}}$ & $30,03 \pm 1,83^{\mathrm{b}}$ \\
LK & $(\mathrm{cm})$ & $14,25 \pm 0,97^{\mathrm{a}}$ & $13,25 \pm 0,94^{\mathrm{b}}$ & $14.18 \pm 0,66^{\mathrm{a}}$ & $13.10 \pm 0,64^{\mathrm{b}}$ \\
TPi & $(\mathrm{cm})$ & $110,43 \pm 4,34^{\mathrm{a}}$ & $105,97 \pm 5,08^{\mathrm{b}}$ & $109.85 \pm 3,48^{\mathrm{a}}$ & $105.03 \pm 3,13^{\mathrm{b}}$
\end{tabular}

Keterangan : Huruf yang beda pada baris yang sama kolom berbeda menunjukkan Beda Nyata $(\mathrm{P}<0,05)$, Panjang Badan (PB), Tinggi Pundak (TP), Lingkar Dada (LD), Dalam Dada (DaD),Lebar Dada (LeD), Lingkar Kanon (LK) dan TPi (Tinggi Pinggul).

Tabel 3. Penciri ukuran dan penciri bentuk tubuh sapi Bali jantan dan betina menggunakan analisiskomponen utama di Kecamatan Pamenang dan Kecamatan Bangko Kabupaten Merangin.

\begin{tabular}{|c|c|c|c|c|c|}
\hline Daerah & $\begin{array}{c}\text { Urai } \\
\text { an }\end{array}$ & & Persamaan & $\begin{array}{l}\text { KT } \\
(\%)\end{array}$ & $\Lambda$ \\
\hline \multirow{4}{*}{$\begin{array}{l}\text { Kecama } \\
\text { tan } \\
\text { Pamena } \\
\text { ng }\end{array}$} & \multirow{2}{*}{$\begin{array}{c}\text { Jant } \\
\text { an }\end{array}$} & $\begin{array}{l}\text { Persamaan Ukuran } \\
\text { Tubuh }\end{array}$ & $\begin{aligned} & 0,394 \mathrm{~PB}+0,250 \mathrm{TP}+\mathbf{0 , 4 0 1} \mathbf{L D}+0,397 \mathrm{DaD}+0,392 \mathrm{LeD} \\
& +0,387 \mathrm{LK}+0,400 \mathrm{Tpi}\end{aligned}$ & 84,6 & $\begin{array}{c}5,9 \\
2\end{array}$ \\
\hline & & $\begin{array}{l}\text { Persamaan Bentuk } \\
\text { Tubuh }\end{array}$ & $\begin{array}{l}=-0,021 \mathrm{~PB}+\mathbf{0 , 9 5 2} \mathbf{T P}-0,083 \mathrm{LD}-0,135 \mathrm{DaD}-0,088 \mathrm{LeD}-0,245 \\
\text { LK }-0,034 \mathrm{Tpi}\end{array}$ & 9,9 & $\begin{array}{c}0,6 \\
9\end{array}$ \\
\hline & \multirow{2}{*}{$\begin{array}{c}\text { Betin } \\
\text { a }\end{array}$} & $\begin{array}{l}\text { Persamaan Ukuran } \\
\text { Tubuh }\end{array}$ & $\begin{array}{l}0,380 \mathrm{~PB}+0,355 \mathrm{TP}+\mathbf{0 , 3 8 8} \mathbf{L D}+0,382 \mathrm{DaD}+0,378 \mathrm{LeD}+ \\
0,375 \mathrm{LK}+0,386 \mathrm{Tpi}\end{array}$ & 78,5 & $\begin{array}{c}5,5 \\
0\end{array}$ \\
\hline & & $\begin{array}{l}\text { Persamaan Bentuk } \\
\text { Tubuh } \\
\end{array}$ & $\begin{array}{l}=0,032 \mathrm{~PB}+\mathbf{0 , 6 5 3} \mathbf{T P}+0,185 \mathrm{LD}-0,242 \mathrm{DaD}-0,554 \mathrm{LeD}-0,315 \\
\mathrm{LK}+0,271 \mathrm{Tpi}\end{array}$ & 6,9 & $\begin{array}{c}0,4 \\
8\end{array}$ \\
\hline \multirow{4}{*}{$\begin{array}{l}\text { Kecama } \\
\text { tan } \\
\text { Bangko }\end{array}$} & \multirow{2}{*}{$\begin{array}{c}\text { Janta } \\
\mathrm{n}\end{array}$} & $\begin{array}{l}\text { Persamaan Bentuk } \\
\text { Tubuh }\end{array}$ & $\begin{array}{l}=0,395 \mathrm{~PB}+0,253 \mathrm{TP}+\mathbf{0 , 4 0 1} \mathbf{L D}+0,397 \mathrm{DaD}+0,379 \mathrm{LeD}+ \\
0,398 \mathrm{LK}+0,400 \mathrm{Tpi}\end{array}$ & 84,2 & $\begin{array}{c}5,8 \\
9\end{array}$ \\
\hline & & $\begin{array}{l}\text { Persamaan Bentuk } \\
\text { Tubuh }\end{array}$ & $\begin{array}{l}=-0,109 \text { PB+ 0,961 TP- } 0,031 \mathrm{LD}-0,113 \mathrm{DaD}-0,182 \mathrm{LeD}-0,097 \\
\text { LK }-0,088 \mathrm{Tpi}\end{array}$ & 9,6 & $\begin{array}{c}0,6 \\
7\end{array}$ \\
\hline & Betin & $\begin{array}{l}\text { Ukuran } \\
\text { uh }\end{array}$ & $\begin{array}{l}0,395 \mathrm{~PB}+0,213 \mathrm{TP}+\mathbf{0 , 4 0 7} \mathbf{L D}+0,404 \mathrm{DaD}+0,395 \mathrm{LeD}+ \\
0,386 \mathrm{LK}+0,406 \mathrm{Tpi}\end{array}$ & 84,2 & $\begin{array}{c}5,8 \\
9\end{array}$ \\
\hline & $\mathrm{a}$ & $\begin{array}{l}\text { Persamaan Bentuk } \\
\text { Tubuh }\end{array}$ & $\begin{array}{l}=-0,216 \text { PB+ 0,964 TP- } 0,041 \mathrm{LD}-0,121 \mathrm{DaD}-0,013 \mathrm{LeD}-0,046 \\
\text { LK }-0,078 \mathrm{Tpi}\end{array}$ & 11,3 & $\begin{array}{c}0,7 \\
9\end{array}$ \\
\hline
\end{tabular}

Keterangan $: \mathrm{PB}=$ Panjang Badan, TP = Tinggi Pundak, LD = Lingkar Dada, DaD = Dalam Dada, dan LeD = Lebar

Dada, LK = Lingkar Kanondan TPi $=$ Tinggi Pinggul.

Tabel 4. Hasil analisis korelasi dan determinasi antara ukuran-ukuran tubuh dengan bobot badan

\begin{tabular}{|c|c|c|c|c|c|c|c|c|}
\hline \multirow{3}{*}{ Variabel } & \multicolumn{4}{|c|}{ Kecamatan Pamenang } & \multicolumn{4}{|c|}{ Kecamatan Bangko } \\
\hline & \multicolumn{2}{|c|}{ Jantan } & \multicolumn{2}{|c|}{ Betina } & \multicolumn{2}{|c|}{ Jantan } & \multicolumn{2}{|c|}{ Betina } \\
\hline & $\mathrm{r}$ & $\mathrm{r}^{2}$ & $\mathrm{r}$ & $\mathrm{r}^{2}$ & $\mathrm{r}$ & $r^{2}$ & $\mathrm{r}$ & $\mathrm{r}^{2}$ \\
\hline Umum & 0,986 & 0,972 & 0,972 & 0,945 & 0,991 & 0,982 & 0,992 & 0,985 \\
\hline $\mathrm{PB}-\mathrm{BB}$ & 0,967 & 0,935 & 0,866 & 0,750 & 0,941 & 0,885 & 0,956 & 0,914 \\
\hline $\mathrm{TP}-\mathrm{BB}$ & 0,532 & 0,283 & 0,747 & 0,558 & 0,574 & 0,329 & 0,438 & 0,192 \\
\hline $\mathrm{LD}-\mathrm{BB}$ & 0,972 & 0,945 & 0,939 & 0,882 & 0,981 & 0,962 & 0,982 & 0,964 \\
\hline $\mathrm{DaD}-\mathrm{BB}$ & 0,925 & 0,856 & 0,821 & 0,674 & 0,927 & 0,859 & 0,970 & 0,941 \\
\hline $\mathrm{LeD}-\mathrm{BB}$ & 0,899 & 0,808 & 0,855 & 0,731 & 0,883 & 0,780 & 0,909 & 0,826 \\
\hline $\mathrm{LK}-\mathrm{BB}$ & 0,929 & 0,863 & 0,827 & 0,684 & 0,937 & 0,878 & 0,941 & 0,855 \\
\hline $\mathrm{TPi}-\mathrm{BB}$ & 0,955 & 0,912 & 0,833 & 0,694 & 0,959 & 0,920 & 0,960 & 0,922 \\
\hline
\end{tabular}

Keterangan : $\mathrm{BB}=$ Bobot Badan, $\mathrm{PB}=$ Panjang Badan, $\mathrm{TP}=$ Tinngi Pundak, LD = Lingkar Dada, DaD = Dalam Dada, LeD = Lebar Dada, TPi = Tinggi Pinggul, LK = Lingkar Kanon.

Persamaan ukuran dan bentuk sapi Bali berdasarkan analisis komponen utama (AKU) di Kecamatan Pamenang dan Kecamatan Bangko disajikan pada tabel 5. Menunjukkan keragaman total komponen utama ke-1 yang disetarakan dengan penciri ukuran tubuh sapi Bali jantan dan betina di Kecamatan Pamenang secara berurutan adalah $84,6 \%$ dan $78,5 \%$, sedangkan di Kecamatan Bangko secara berurutan $84,2 \%$ dan $84,2 \%$. Keragaman total komponen utama ke-2 yang disetarakan dengan penciri bentuk di kecamatan Pamenang baik pada ternak jantan maupun betina secara berurutan adalah 9,9\% dan 6,9\% sedangkan di 
Kecamatan Bangko secara adalah 9,6\% dan $11,3 \%$.

Hal ini menunjukan bahwa variabel ukuran tubuh sapi Bali jantan dan betina yang berpengaruh terhadap penciri ukuran baik di Kecamatan Pamenang dan Kecamatan Bangko dari berbagai ukuran tubuh yang berkorelasi positif dan terbesar yaitu lingkar dada (LD). Sedangkan penentu bentuk tubuh sapi Bali jantan dan betina yang berkorelasi positif dan terbesar baik di Kecamatan Pamenang maupun Kecamatan Bangko adalah tinggi pundak (TP). Hasil penelitian ini tidak jauh berbeda dengan hasil penelitian Hikmawaty et al (2014) yang menyatakan bahwa lingkar dada merupakan factor penentu ukuran pada sapi Bali baik di daerah BPTU Pulukan Bali, VBC Kabupaten Barru Sulses dan BPTHMT Serading NTB. Selanjutnya dinyatakan beberapa hasil penelitian menunjukkan bahwa secara umum penciri ukuran lingkar dada berkorelasi positif dan tertinggi dibandingkan ukuran tubuh lainnya pada sapi Bali (Hikmawati et al, 2018 ; Mahmudi et al., 2019).

Korelasi dan determinasi ukuran-ukuran tubuh dengan bobot badan sapi Bali di Kecamatan Pamenang dan Kecamatan Bangko

Hasil analisis korelasi dan determinasi antara ukuran-ukuran tubuh dengan bobot badan di sajikan pada tabel 4. Tabel 4. Menunjukan bahwa keeratan hubungan antara ukuran-ukuran tubuh dengan bobot badan sapi Bali jantan dan betina baik di Kecamatan Pamenang maupun Kecamatan Bangko secara berurutan adalah $0,986,0,972,0,991$ dan 0,992. Nilai koefisien determinasi $\left(\mathrm{r}^{2}\right)$ antara ukuran-ukuran tubuh dengan bobot badan sapi Bali jantan dan betina baik di Kecamatan Pamenang secara berurutan adalah 0,972 dan 0,945 maupun Kecamatan Bangko secara berurutan 0,982 dan 0,985. Artinya 97,2\% dan 98,2\% bobot badan sapi Bali jantan di Kecamatan Pamenang dan Bangko ditentukan oleh ukuran-ukuran tubuh, sedangkan sisanya di pengaruhi faktor lain yang tidak teramati, sedangkan pada sapi Bali betina di Kecamatan Pamenang dan Bangko secara berurutan adalah $94,5 \%$ dan $98,5 \%$ nilai bobot badan ditentukan oleh ukuran-ukuran tubuh sedangkan sisa nya di pengaruhi oleh faktor lain yang tidak teramati.
Secara parsial nilai korelasi tertinggi antara ukuran-ukuran tubuh dengan bobot badan sapi Bali jantan dan betina di dua kecamatan adalah Lingkar Dada. Keeratan hubungan antara lingkar dada dengan bobot badan sapi Bali jantan dan betina di Kecamatan Pamenang secara berurutan 0,972, dan 0,939 sedangkan sapi Bali di Kecamatan Bangko secara berurutan 0,981 dan 0,982. Menurut pendapat Niam et al. (2012) koefisien korelasi antara lingkar dada dengan bobot badan pada sapi Bali betina menunjukkan bahwa, lingkar dada pada setiap umur memiliki keeratan hubungan yang lebih baik dengan bobot badan jika dibandingkan dengan tinggi pundak, panjang badan dan lebar dada pada umur yang sama. Nilai determinasi $\left(r^{2}\right)$ bobot badan dengan lingkar dada sapi Bali jantan dan betina di Kecamatan Pamenang secara berurutan adalah 0,945\% dan 0,882\% sedangkan Kecamatan Bangko secara berurutan adalah $0,962 \%$ dan $0,964 \%$. Artinya $94,5 \%$ dan $88,2 \%$ bobot badan sapi Bali jantan dan betina di Kecamatan Pamenang ditentukan oleh lingkar dada selebihnya di pengaruhi oleh faktor lain yang tidak teramati, sedangkan pada sapi Bali jantan dan betina di Kecamatan Bangko 96,2\% dan $96,4 \%$ bobot badan ditentukan oleh lingkar dada sedangkan sisanya di pengaruhi oleh faktor lain yang tidak teramati. Artinya lingkar dada dapat digunakan untuk mengestimasi bobot badan pada sapi Bali jantan dan betina baik di Kecamatan Pamenang maupun di Kecamatan Bangko. Kondisi ini menunjukkan bahwa lingkar dada sebagai faktor yang paling erat hubungannya dibanding ukuran tubuh lainnya terhadap bobot badan. Menurut Hikmawaty et al. (2018) bahwa sapi Bali pada kelompok tani ternak Paraita memiliki nilai koefisien determinasi sebesar 99,84\% yang berarti bahwa variabel-variabel yang diukur berpengaruh terhadap bobot badan sebesar 99,84\%.

\section{Perbandingan Sapi Bali Di Kecamatan Pamenang dan Kecamatan Bangko Dengan Persyaratan Minimum Bibit Sapi Bali Berdasarkan SNI}

Ukuran-ukuran tubuh sapi Bali jantan dan betina di Kecamatan Pamenang dan Kecamatan Bangkodan SNI di sajikan pada tabel 5. 
Tabel 5. Ukuran-ukuran tubuh sapi Bali jantan dan betina di Kecamatan Pamenang dan Kecamatan Bangko dengan SNI

\begin{tabular}{ccccccc}
\hline \multirow{2}{*}{$\begin{array}{c}\text { Jenis } \\
\text { Kelamin }\end{array}$} & Variabel & & \multicolumn{3}{c}{ Daerah } \\
\cline { 4 - 7 } & & & Pamenag & SNI & Bangko & SNI \\
\hline \multirow{3}{*}{ Jantan } & Panjang Badan & $\mathrm{cm}$ & $114,30^{\mathrm{a}}$ & $115^{\mathrm{a}}$ & $113,18^{\mathrm{a}}$ & $115^{\mathrm{a}}$ \\
& Tinggi Pundak & $\mathrm{cm}$ & $104,87^{\mathrm{a}}$ & $105^{\mathrm{a}}$ & $104,85^{\mathrm{a}}$ & $105^{\mathrm{a}}$ \\
& Lingkar Dada & $\mathrm{cm}$ & $140,83^{\mathrm{a}}$ & $142^{\mathrm{b}}$ & $139,78^{\mathrm{a}}$ & $142^{\mathrm{b}}$ \\
& Panjang Badan & $\mathrm{cm}$ & $104,43^{\mathrm{a}}$ & $101^{\mathrm{b}}$ & $104,10^{\mathrm{a}}$ & $101^{\mathrm{b}}$ \\
\cline { 3 - 6 } Betina & Tinggi Pundak & $\mathrm{cm}$ & $103,33^{\mathrm{a}}$ & $100^{\mathrm{b}}$ & $102,83^{\mathrm{a}}$ & $100^{\mathrm{b}}$ \\
& Lingkar Dada & $\mathrm{cm}$ & $128,70^{\mathrm{a}}$ & $124^{\mathrm{b}}$ & $127,60^{\mathrm{a}}$ & $124^{\mathrm{b}}$ \\
\hline
\end{tabular}

Keterangan:Superskrip yang beda pada baris yang sama menunjukkan perbedaan yang nyata $(\mathrm{P}<0,05)$, sedangkan superskrip yang sama pada baris yang sama menunjukkan tidak berbeda nyata $(\mathrm{P}>0,05)$.

Berdasarkan Tabel 5. Rataan ukuran tubuh sapi Bali jantan dan betina Kecamatan Pamenang > dibandingkan sapi Bali Kecamatan Bangko. Hasil analisis statistik uji t menunjukkan bahwa ukuran-ukuran tubuh sapi Bali jantan dan betina di Kecamatan Pamenang dan Bangko lebih rendah dibandingkan dengan SNI kelas I dan kelas II. Rataan panjang badan dan tinggi pundak sapi Bali jantan di Kecamatan Pamenang dan Bangko berbeda tidak nyata $(P>0,05)$ dengan syarat minimum kuantitatif bibit sapi Bali kelas III dan rataan lingkar dada sapi Bali jantan di Kecamatan Pamenang dan Bangko berbeda nyata $(\mathrm{P}<0,05)$ dengan syarat minimum kuantitatif bibit sapi Bali kelas III . Artinya ukuran-ukuran tubuh sapi Bali jantan di Kecamatan Pamenang dan Bangko lebih rendah dari syarat minimum kuantitatif bibit sapi Bali kelas III. Sedangkan rataan panjang badan, tinggi pundak dan lingkar dada di Kecamatan Pamenang dan Kecamatan Bangko hasil analisis uji t menunjukan bahwa ukuran tubuh sapi Bali betina berbeda nyata $(\mathrm{P}<0,05)$ dengan syarat minimum kuantitatif bibit sapi Bali kelas III, artinya lebih tinggi dari syarat minimum kuantitatif bibit sapi Bali kelas III. Tinggi rendahnya nilai ukuran-ukuran tubuh sapi Bali jantan dan betina antara Kecamatan Pamenang dan Kecamatan Bangko dibandingkan dengan SNI (2017) disebabkan pengaruh faktor genetik, sistem perkawinan dan manajemen pemeliharaan yang berbeda. Penelitian ini sesuai dengan pendapat Hikmawaty et al. (2018) bahwa bobot badan ternak dapat berbeda antara satu sama lain yang kemungkinan adanya perbedaan keragaman disebabkan

oleh potensi genetik, lokasi asal, sistem pemeliharaan dan perkawinan yang ditetapkan di daerah tersebut.

\section{KESIMPULAN DAN IMPLIKASI}

Bobot badan, pertambahan bobot badan harian dan ukuran ukuran tubuh sapi Bali jantan dan betina umur $\mathrm{I}_{1}$ di Kecamatan Pamenang lebih tinggi dibandingkan dengan Kecamatan Bangko. Faktor penentu ukuran-ukuran tubuh sapi Bali di Kecamatan Pamenang dan Kecamatan Bangko adalah Lingkar Dada (LD). Faktor penentu bentuk tubuh sapi Bali di Kecamatan Pamenang dan Kecamatan Bangko

Tinggi Pundak (TP). Korelasi antara ukuranukuran tubuh dengan bobot badan sapi Bali jantan dan betina di Kecamatan Pamenang dan Kecamatan Bangko yang tertinggi adalah Lingkar Dada (LD). Beberapa ukuran tubuh sapi Bali jantan dan betina di Kecamatan Pamenang dan Kecamatan Bangko sudah memenuhi persyaratan minimum Standar Nasional Indonesia kelas III.

\section{DAFTAR PUSTAKA}

Badan Pusat Statistik Kabupaten Merangin. 2018. Kabupaten Merangin Dalam Angka: Badan Pusat Statistik Kabupaten Merangin.

Badan Pusat Statistik Provinsi Jambi. 2018. Provinsi Jambi Dalam Angka: Badan Pusat Statistik Provinsi Jambi.

Chadijah, St. 2012. Pengaruh Umur Dan Jenis Kelamin Terhadap Pertambahan Bobot Badan Sapi Bali. Artikel Ilmiah Produksi Ternak, Agustus 2012.

Direktorat Jenderal Peternakan dan Kesehatan Hewan. 2018. Statistik Peterakan dan Kesehatan Hewan. Jakarta: Direktorat Jenderal Peternakan dan Kesehatan Hewan. 
Gaspersz, V. 2006.Teknik Analisis dalam Penelitian Percobaan.Penerbit. Tarsito Bandung.

Harahap, A.U. 2018. Analisa morfometrik pada sapi lokal di Kabupaten Padang Lawas Utara. Jurnal Lppm Ugn. 8 (4).

Hartati, Sumadi, Subandriyo dan T, Hartatik. 2010. Keragaman morfologi dan diferensiasi genetik sapi Peranakan Ongole di peternakan rakyat. JITV. 15 : 72 - 80.

Hikmawaty, A Gunawan, Rr Noor dan Jakaria. 2014. Identifikasi ukuran tubuh dan bentuk tubuh sapi bali di beberapa pusat pembibitan melalui pendekatan analisis komponen utama. Jurnal Ilmu Produksi dan Teknologi Hasil Peternakan. 2 (1) : 231 - 237.

Hikmawaty, Bellavista , A. T. B. A. Mahmud dan A. Salam. 2018. Korelasi bobot badan dan variabel-variabel ukuran tubuh sebagai dasar seleksi calon induk sapi Bali. Agrovital Uurnal Ilmu Pertanian Universitas Al Asyariah Mandar). 3 (1). 11 -13.
Madu, E. Y, I. N. Suartha dan I. W. Batan. 2015. Status praesen sapi bali dara. Indonesia Medicus Veterinus. 4 (5): 437-444.

Mahmudi, R., Priyanto dan Jakaria. 2019. Karakteristik morfometrik sapi Aceh, sapi po dan sapi Bali berdasarkan analisis komponen utama (aku). Jurnal Ilmu Produksi Dan Teknologi Hasil Peternakan. 7 (1) : $35-40$.

Ni'am H. U. M. A, Purnomoadi dan S, Dartosukarno. 2012. Hubungan antara ukuran-ukuran tubuh dengan bobot badan sapi bali betina pada berbagai kelompok umur.Animal Agriculture Journal. 1 (1) : 541 $-556$.

Setiyono, A. H. A. Kusuma dan Rusman. 2017. Pengaruh bangsa, umur, jenis kelamin terhadap kualitas daging sapi potong di daerah istimewa Yogyakarta. Buletin Peternakan. 41.176-186. 